\title{
NGNP Graphite Testing and Qualification Specimen Selection Strategy
}

\section{Robert Bratton}

Timothy Burchell

May 2005

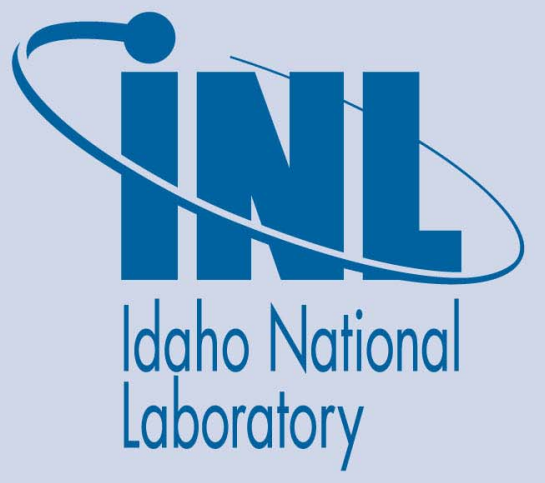

The INL is a U.S. Department of Energy National Laboratory operated by Battelle Energy Alliance 
INL/EXT-05-00269

\title{
NGNP Graphite Testing and Qualification Specimen Selection Strategy
}

\author{
Robert Bratton ${ }^{\mathrm{a}}$ \\ Timothy Burchell
}

adaho National Laboratory

${ }^{\mathrm{b}}$ Oak Ridge National Laboratory

May 2005

\section{Idaho National Laboratory \\ Idaho Falls, Idaho 83415}

Prepared for the

U.S. Department of Energy

Office of Nuclear Energy

Under DOE Idaho Operations Office

Contract DE-AC07-05ID14517 


\section{ABSTRACT}

The available grades of graphite for the NGNP are reviewed. A selection matrix is presented outlining the available grades for the NGNP graphite irradiation program based upon input from potential NGNP vendors, graphite manufactures, and graphite experts. 


\section{SUMMARY}

In May 2004, the U.S. Department of Energy (DOE) released a Request for Information and Expressions of Interest on the Next Generation Nuclear Plant (NGNP), the objective of which was ". . . to conduct research, development, and demonstration of a next-generation nuclear power reactor in order to establish advanced technology for the future production of safe, efficient, and environmentally acceptable power and to demonstrate the economic and technical feasibility of such facilities to the U.S. electric power industry."

The NGNP reference concept is a helium-cooled, graphite-moderated, thermal neutron spectrum reactor with an outlet temperature of 900 to $950{ }^{\circ} \mathrm{C}$ and a 40 to 60 -year operating lifetime. The reactor core is currently envisioned to be a prismatic graphite block type core. However, it is feasible to also consider a pebble-bed gas-cooled reactor. Plant size, reactor thermal power, and core configuration will be designed to ensure removal of passive decay heat without fuel damage or radioactive material releases if an accident occurs. The initial fuel cycle will be a once-through use of very high burnup, low-enriched uranium.

The grade of nuclear graphite $(\mathrm{H}-451)$ previously used in the USA is no longer available. New graphites have been developed and are currently being considered as candidates for the NGNP. Early in the program, we will review and document the existing data from all available sources on the properties of these graphites. Irradiation data from ongoing experiments in the Petten Reactor (European program) will be of great value. A complete properties database on the new, available candidate grades of graphite must be developed to support the design of graphite core components. Data are required for the physical, mechanical (including radiation induced creep), and oxidation properties of graphites. Moreover, the data must be statistically sound and take account of inbillet, between billets, and lot-to-lot variations of properties. The data will be needed to support the ongoing development of the risk-informed American Society of Mechanical Engineers graphite design codes. Previous Fort St. Vrain designs used deterministic performance models for H-451, while the NGNP will use new graphite grades and risk-informed performance models. A radiation effects database must be developed for the currently available graphite materials, and this requires a substantial graphite irradiation program irradiation properties program.

Candidate graphite materials are presented in Table 1. However, certain tests must be conducted to verify that the candidate's relevant material properties meet the claims of the manufacturer. The preliminary selection process will need limited irradiation response data for the different grades of graphite. These test results will be used to establish the general behavior of a particular grade of graphite and confirm that it behaves similarly to previously "qualified" (for other nuclear reactors), near-isotropic, nuclear grades of graphite. 
Table 1. Graphite selection matrix.

\begin{tabular}{|c|c|c|c|c|}
\hline Graphite & $\begin{array}{l}\text { Reactor } \\
\text { Vendor }\end{array}$ & Proposed Use & $\begin{array}{l}\text { Capsule } \\
\text { Location } \\
\end{array}$ & Remarks \\
\hline H-451 & GA & $\begin{array}{l}\text { Prismatic fuel element and replaceable } \\
\text { reflector. }\end{array}$ & Creep & $\begin{array}{l}\text { Historical Reference. } \\
\text { Only a few samples. }\end{array}$ \\
\hline IG-110 & $\begin{array}{l}\text { JAERI } \\
\text { China }\end{array}$ & $\begin{array}{l}\text { Prismatic fuel element, replaceable } \\
\text { reflector, and core support pedestals. }\end{array}$ & Creep & $\begin{array}{l}\text { Historical Reference. } \\
\text { Only a few samples. } \\
\text { Currently being used in the } \\
\text { HTTR and HTR-10. }\end{array}$ \\
\hline PCEA & AREVA & $\begin{array}{l}\text { Prismatic fuel and replaceable block. } \\
\text { Pebble bed reflector and insulation blocks. }\end{array}$ & Creep & $\begin{array}{l}\text { Areva wants to construct the } \\
\text { entire graphite core out of the } \\
\text { same graphite. }\end{array}$ \\
\hline NBG-18 & PBMR & $\begin{array}{l}\text { Prismatic fuel element and replaceable } \\
\text { reflector. } \\
\text { Pebble bed reflector structure and } \\
\text { insulation blocks. }\end{array}$ & Creep & $\begin{array}{l}\text { Candidate for PBMR } \\
\text { replaceable reflector. }\end{array}$ \\
\hline NBG-17 & AREVA & $\begin{array}{l}\text { Prismatic fuel element and replaceable } \\
\text { reflector. } \\
\text { Pebble bed reflector structure and } \\
\text { insulation blocks. }\end{array}$ & Creep & $\begin{array}{l}\text { Areva wants to construct the } \\
\text { entire graphite core out of the } \\
\text { same graphite. } \\
\text { NBG-17 is finer grain than } \\
\text { NBG-18. }\end{array}$ \\
\hline IG-430 & JAERI & $\begin{array}{l}\text { Prismatic fuel element, replaceable } \\
\text { reflector, and core support pedestals. }\end{array}$ & Creep & $\begin{array}{l}\text { JAERI wants to use this } \\
\text { graphite in the GTHTR } 300 .\end{array}$ \\
\hline HLM & & Prismatic large permanent reflector. & Piggyback & $\begin{array}{l}\text { Fort St. Vrain permanent } \\
\text { reflector. Similar to PGX. }\end{array}$ \\
\hline PGX & $\begin{array}{l}\text { AREVA } \\
\text { JAERI }\end{array}$ & Prismatic large permanent reflector. & Piggyback & $\begin{array}{l}\text { AREVA may use this } \\
\text { material; preference is to use } \\
\text { PCEA or NBG-17 for } \\
\text { permanent reflector. HTTR } \\
\text { permanent structure. }\end{array}$ \\
\hline NBG-25 & & Core support candidate. & Piggyback & Isostatic fine grain. \\
\hline 2020 & & $\begin{array}{l}\text { Prismatic core support pedestals and } \\
\text { blocks. }\end{array}$ & Piggyback & $\begin{array}{l}\text { Fine grain isotropic. } \\
\text { NPR candidate material. }\end{array}$ \\
\hline PCIB & & Core support candidate. & Piggyback & Fine grain isotropic. \\
\hline BAN & & & Piggyback & $\begin{array}{l}\text { Experimental graphite with } \\
\text { potentially superior } \\
\text { irradiation life. }\end{array}$ \\
\hline NBG-10 & PBMR & $\begin{array}{l}\text { Prismatic Fuel element and replaceable } \\
\text { reflector. } \\
\text { Pebble bed reflector structure and } \\
\text { insulation blocks. }\end{array}$ & Piggyback & $\begin{array}{l}\text { PBMR's original choice for } \\
\text { replaceable reflector. } \\
\text { Price/performance will be the } \\
\text { basis between NBG-18 and } \\
\text { NBG-10. }\end{array}$ \\
\hline HOPG & & $\begin{array}{l}\text { Needed to determine change in crystalline } \\
\text { structure. }\end{array}$ & Piggyback & $\begin{array}{l}\text { Provides insight to single } \\
\text { crystal changes during } \\
\text { neutron irradiation. }\end{array}$ \\
\hline $\begin{array}{l}\text { A3 } \\
\text { Matrix }\end{array}$ & & $\begin{array}{l}\text { Needed to determine fuel compact } \\
\text { irradiated material behavior. }\end{array}$ & Piggyback & \\
\hline PPEA & & $\begin{array}{l}\text { Prismatic fuel and replaceable block; } \\
\text { Pebble bed reflector and insulation blocks }\end{array}$ & Piggyback & $\begin{array}{l}\text { Comparison of irradiation } \\
\text { performance between } \\
\text { petroleum and pitch coke }\end{array}$ \\
\hline
\end{tabular}


Billets of the following grades should be purchased for inclusion in our irradiation program and for subsequent preirradiation characterization. In several instances, a sufficient quantity of graphite has been (or will be) supplied free of charge by the supplier for our irradiation experiment needs. Quantities needed for the irradiation and preirradiation characterization should be purchased this or next fiscal year. Billet quantities should be purchased when funding is available to perform a more extensive material characterization to determine variances from billet to billet and between lots.

\begin{tabular}{|l|l|l|}
\hline \multicolumn{1}{|c|}{ Grade } & \multicolumn{1}{|c|}{ Manufacturer } & \multicolumn{1}{c|}{ Comments } \\
\hline PCEA & Graftech International & $\begin{array}{l}\text { Extruded, candidate for high dose regions of } \\
\text { VHTR concepts. }\end{array}$ \\
\hline NBG-17 & SGL & $\begin{array}{l}\text { Vibrationally molded, candidate for high dose } \\
\text { regions of VHTR concepts. }\end{array}$ \\
\hline NBG-18 & SGL & $\begin{array}{l}\text { Vibrationally molded, candidate for high dose } \\
\text { regions of VHTR concepts. }\end{array}$ \\
\hline IG-430 & Toyo Tanso & $\begin{array}{l}\text { Vibrationally molded, candidate for high dose } \\
\text { regions of VHTR concepts. }\end{array}$ \\
\hline
\end{tabular}

Billets of the following grades will be required for detailed characterization. Guidance from potential reactor vendors will be used to determine which of these grades will be subjected to detailed characterization. Smaller quantities may have to be purchased for irradiation experiments, although in many cases these will be supplied free of cost by the manufacturers. Quantities needed for the irradiation and preirradiation characterization should be purchased this or next fiscal year. Billet quantities should be purchased when funding is available to perform a more extensive material characterization to determine variances from billet to billet and between lots.

\begin{tabular}{|l|l|l|}
\hline \multicolumn{1}{|c|}{ Grade } & \multicolumn{1}{|c|}{ Manufacturer } & \multicolumn{1}{c|}{ Comments } \\
\hline PGX & Graftech International & $\begin{array}{l}\text { Molded, candidate for low dose regions of } \\
\text { VHTR concepts }\end{array}$ \\
\hline PCIB & Graftech International & $\begin{array}{l}\text { Isostatically molded, candidate for low dose } \\
\text { regions of VHTR concepts }\end{array}$ \\
\hline NBG-10 & SGL & $\begin{array}{l}\text { Extruded, candidate for low and high dose } \\
\text { regions of VHTR concepts }\end{array}$ \\
\hline NBG-25 & SGL & $\begin{array}{l}\text { Extruded, candidate for low dose regions of } \\
\text { VHTR concepts }\end{array}$ \\
\hline 2020 & Carbone of America & $\begin{array}{l}\text { Extruded, candidate for low dose regions of } \\
\text { VHTR concepts }\end{array}$ \\
\hline PPEA & Graftech International & $\begin{array}{l}\text { Extruded, candidate for low dose regions of } \\
\text { VHTR concepts }\end{array}$ \\
\hline
\end{tabular}


The following grades will be included in our irradiation experiments only, no characterization is planned, and thus costs will be minimal.

\begin{tabular}{|l|l|l|}
\hline \multicolumn{1}{|c|}{ Grade } & \multicolumn{1}{|c|}{ Manufacturer } & \multicolumn{1}{c|}{ Comments } \\
\hline BAN & Graftech International & $\begin{array}{l}\text { Extruded, candidate for high dose regions of } \\
\text { VHTR concepts. }\end{array}$ \\
\hline HOPG & Advanced Ceramics & $\begin{array}{l}\text { Vapor deposited and compression annealed. A } \\
\text { model material for the graphite single crystal. }\end{array}$ \\
\hline A3-matrix & $\begin{array}{l}\text { Oak Ridge National } \\
\text { Laboratory }\end{array}$ & $\begin{array}{l}\text { Hot pressed graphite/carbon used for the } \\
\text { matrix of AGFR fuel compacts. }\end{array}$ \\
\hline
\end{tabular}




\section{CONTENTS}

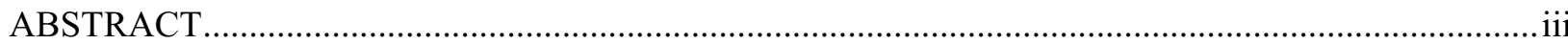

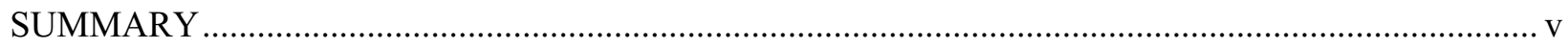

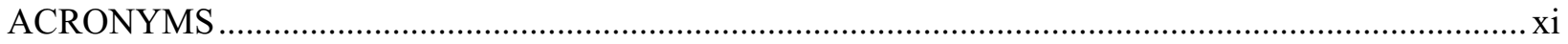

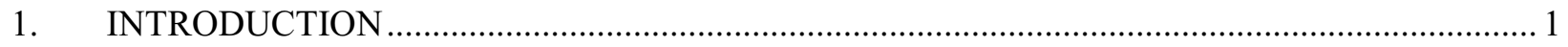

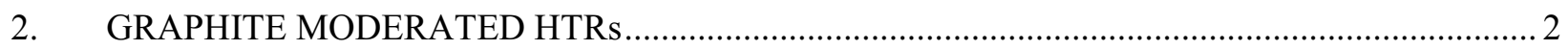

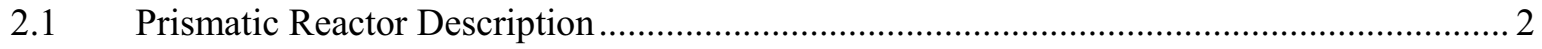

3. GRAPHITE MANUFACTURE AND PROPERTIES .......................................................... 8

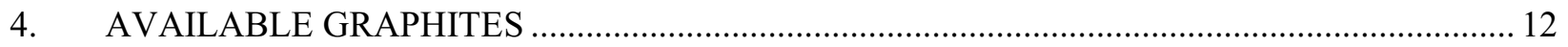

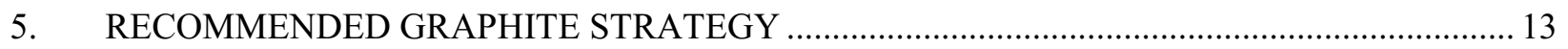

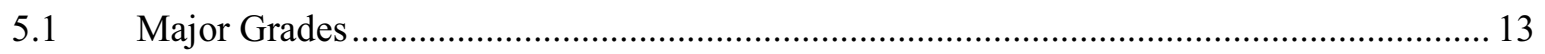

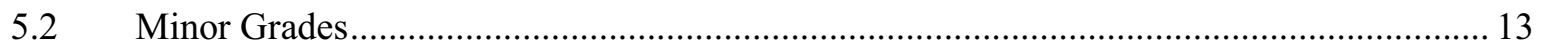

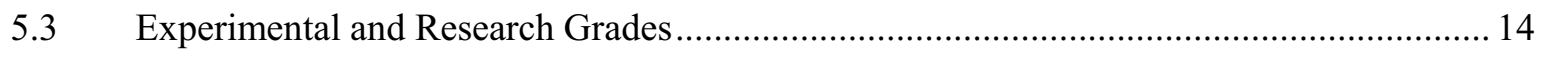

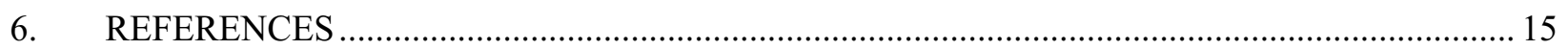

FIGURES

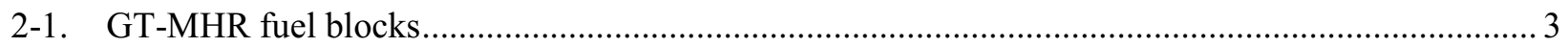

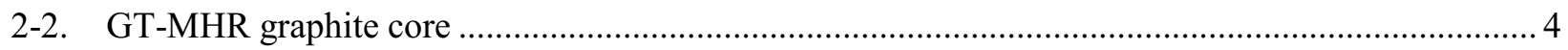

2-3. The graphite core internals of the Pebble Bed Modular Reactor....................................................5

2-4. The central graphite column of the Pebble Bed Modular Reactor ................................................ 6

2-5. The inner and outer graphite side reflector of the Pebble Bed Modular Reactor ............................. 7

3.1. The process step in the manufacturing of nuclear graphit ......................................................... 8

3-2. HTTR graphite fuel block undergoing machining........................................................... 9

3-3. AGC-1 Advanced Test Reactor graphite irradiation capsule ................................................... 11

TABLES

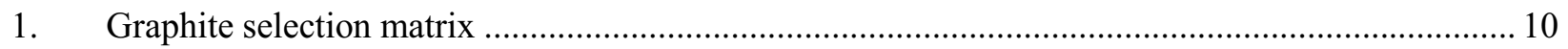




\section{ACRONYMS}

ASME American Society of Mechanical Engineers

ASTM American Society for Testing and Materials

AVR Albeitsgemeinschaft Versuchsreaktor

DOE U.S. Department of Energy

GA General Atomics

GIF Generation IV International Forum

GT-MHR Gas Turbine-Modular Helium Reactor

HTTR High-Temperature Engineering Test Reactor

NGNP Next Generation Nuclear Plant

PBMR Pebble Bed Modular Reactor

PBR pebble bed reactor

PMR prismatic modular reactor

THTR Thorium Hochtemperatur Reaktor

VHTR very high temperature reactor 


\section{Milestone Report: NGNP Graphite Selection Strategy}

\section{INTRODUCTION}

In May 2004, the U.S. Department of Energy (DOE) released a Request for Information and Expressions of Interest on the Next Generation Nuclear Plant (NGNP), the objective of which was "... to conduct research, development, and demonstration of a next-generation nuclear power reactor in order to establish advanced technology for the future production of safe, efficient, and environmentally acceptable power and to demonstrate the economic and technical feasibility of such facilities to the U.S. electric power industry."

The NGNP reference concept is a helium-cooled, graphite-moderated, thermal neutron spectrum reactor with an outlet temperature of 900 to $950{ }^{\circ} \mathrm{C}$ or higher and a 40 to 60 -year operating lifetime. The reactor core is currently envisioned to be a prismatic graphite block type core. However, it is feasible to also consider a pebble-bed gas-cooled reactor. Plant size, reactor thermal power, and core configuration will be designed to ensure removal of passive decay heat without fuel damage or radioactive material releases if an accident occurs. The initial fuel cycle will be a once-through use of very high burnup, lowenriched uranium.

The basic technology for the NGNP has been established in former high-temperature gas-cooled reactor plants (e.g., DRAGON, Peach Bottom, Albeitsgemeinschaft Versuchsreaktor [AVR], Thorium Hochtemperatur Reaktor [THTR], and Fort St. Vrain). ${ }^{1}$ These reactor designs represent two design categories: the pebble bed reactor (PBR) and the prismatic modular reactor (PMR). Commercial examples of potential NGNP candidates are the Gas Turbine-Modular Helium Reactor (GT-MHR) from General Atomics (GA), the High Temperature Reactor concept from AREVA, and the Pebble Bed Modular Reactor (PBMR) from PBMR consortium. Furthermore, the Japanese High-Temperature Engineering Test Reactor (HTTR) and Chinese High-Temperature Reactor (HTR-10) are demonstrating the feasibility of the reactor components and materials needed for NGNP. (The HTTR reached a maximum coolant outlet temperature of $950^{\circ} \mathrm{C}$ in April 2004.) Therefore, the NGNP focuses on building a demonstration plant, rather than simply confirming the basic feasibility of the concept.

Renewed interest in very high temperature reactor (VHTR) concepts, such as the PBMR and the NGNP, has prompted graphite manufacturers to develop new nuclear grade graphites. They have accomplished this in discussion with the reactor vendors and graphite experts. Consequently, there are today several new graphites available for use in the NGNP, although there are no irradiation effects data for these grades. Here we review the available grades and their potential application in NGNP concepts. Moreover, recommendations are made regarding the selection of grades to be included in the USA program. 


\section{GRAPHITE MODERATED HTRs}

Graphite is the major structural component and nuclear moderator in the NGNP core. The graphites used previously in the high temperature gas reactor programs in the USA are no longer in production, and thus replacement graphites must be found. Hence, it will be necessary to qualify new grades of graphite for use in the NGNP. Fortunately, potential candidates currently exist, including fine-grained isotropic, molded or isostatically pressed, high-strength graphite suitable for core support structures, fuel elements and replaceable reactor components, as well as near-isotropic, extruded, nuclear graphite suitable for the above-mentioned structures and for the large permanent reflector components. These candidates would meet the requirements of the draft American Society for Testing and Materials (ASTM) materials specification for nuclear grade graphite. Graphite is a complex material whose structure and properties reflect the raw materials used in its manufacture, the processing techniques, and the thermal history of the material. Our understanding of neutron irradiation damage in graphite is well developed. However, fundamental models relating specific structures at the micro and macrostructural level to the irradiation behavior are less well developed, and thus an extensive irradiation program is needed to develop the models relating structure to the irradiation behavior for the new graphites of interest.

\subsection{Prismatic Reactor Description}

The GT-MHR graphite components will be discussed initially, and the PBR components will be subsequently discussed. The discussion provides some specific information based on the GT-MHR and PBMR conceptual designs. However, the actual conceptual design selected for the NGNP could be different from the information noted. Therefore, the information provided should be viewed as illustrative but not specific to the NGNP. The current General Atomic GT-MHR design has an $850^{\circ} \mathrm{C}$ average outlet temperature with a variation between the hottest and coolest flow channels of about $300^{\circ} \mathrm{C}$ (i.e. a hot channel outlet temperature of about $1000^{\circ} \mathrm{C}$ ). General Atomics is expected to modify the GT-MHR design to achieve the required NGNP average outlet temperature of 900 to $950^{\circ} \mathrm{C}$ (and a hot channel temperature of about 1050 to $1000^{\circ} \mathrm{C}$ ). Similarly, both Areva and PBMR are expected to modify their designs to achieve a 900 to $950^{\circ} \mathrm{C}$ average outlet temperature.

The graphite core of the GT-MHR is a right circular cylinder composed of 102 columns each containing 10 blocks. A standard block (see Figure 2-1) is hexagonal in shape with a dimension of $0.36 \mathrm{~m}$ across the flat and height of $0.8 \mathrm{~m}$. The cylinder is arranged in 11 circular rings. The inner reflector uses the first five rings; the active core uses Rings 6,7, and 8; the outer reflector is composed of Rings 9 and 10; and Ring 11 is the permanent outer reflector. On top of the core column is a reflector block and a half height upper plenum block that caps the column. Below the core column is a bottom reflector block and two half-height insulation graphite blocks. Under each column is a graphite pedestal. The pedestals rest on two additional insulation blocks (graphite or ceramic), which in turn sit on the core support floor.

Each block has four dowel pins protruding from the top; subsequently, each block has four dowel pinholes in the bottom. These dowel pins lock the column together. The thermal expansion and flow induced motion in each block creates shear stresses on the pins and reactive stresses in the dowel pinholes.

The top and bottom insulator graphite blocks make up the lower plenum and insulate the top and bottom of the core. These blocks see fluences on the order of $1.8 \mathrm{E} 16 \mathrm{n} / \mathrm{cm}^{2}$ per year $(\mathrm{E}>0.1 \mathrm{MeV})$ and negligible dpa. Normal operating temperatures are $500^{\circ} \mathrm{C}$ for the top blocks with an inlet temperature of $450^{\circ} \mathrm{C}$ and about $1,000^{\circ} \mathrm{C}$ for the hottest bottom blocks. The off-normal temperatures are $1,100^{\circ} \mathrm{C}$ for the top blocks and $600{ }^{\circ} \mathrm{C}$ for the bottom blocks. This is due to a flow reversal in the core during off-normal conditions. 

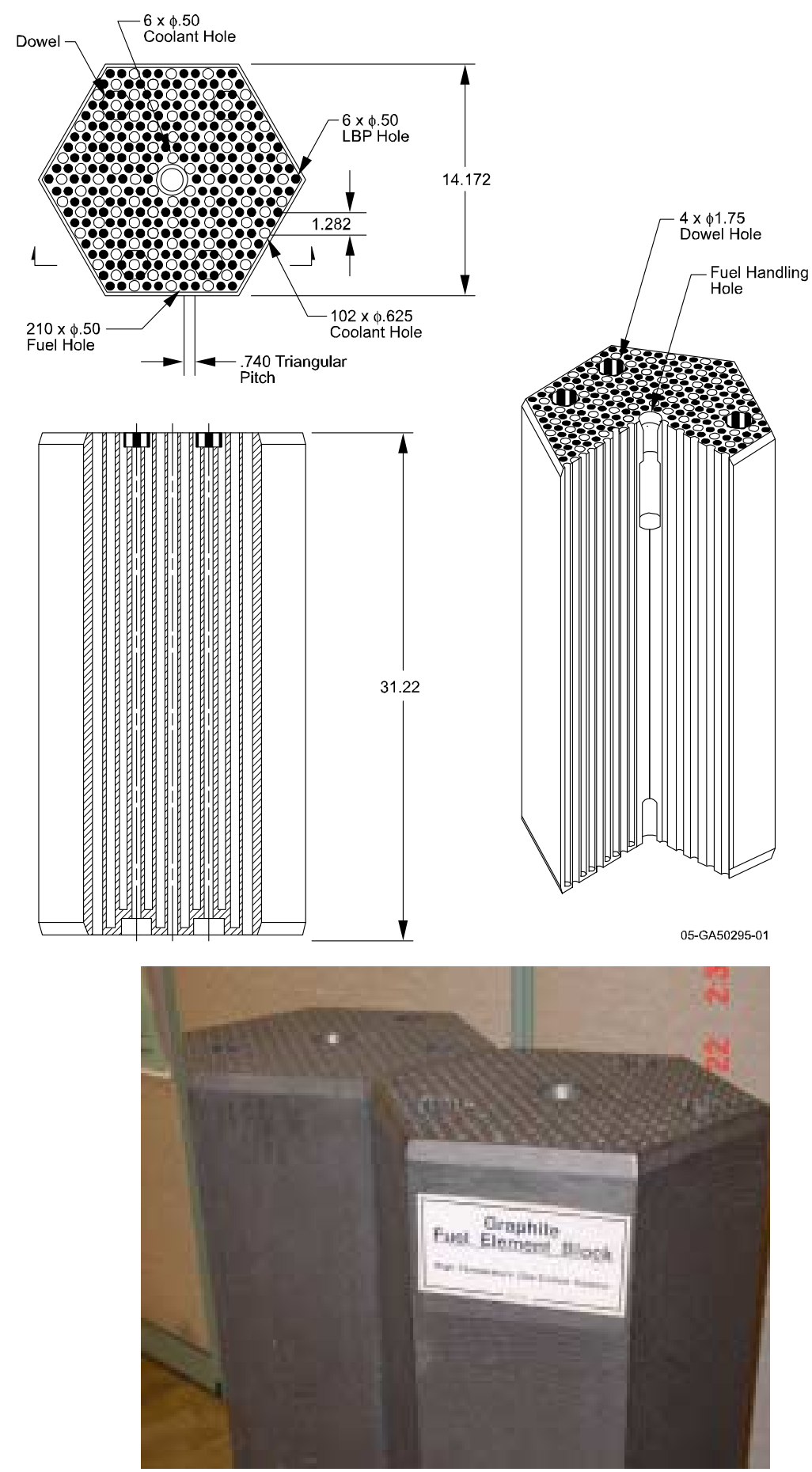

Figure 2-1. GT-MHR fuel blocks. 
The core pedestal supports are graphite columns that support each hexagonal column in the core except for the permanent reflectors. Spaces between the pedestals create the lower plenum of the reactor where all the coolant channels flow; see Figure 2-2. The fluence levels are higher in the plenum than in the insulator blocks, $3.7 \mathrm{E} 16 \mathrm{n} / \mathrm{cm}^{2}$ per year with negligible dpa. Temperatures in the lower plenum reach between 900 to $1000^{\circ} \mathrm{C}$ during normal operation with off-normal temperatures reaching $1,600^{\circ} \mathrm{C}$.

Upper plenum graphite blocks are half the length of regular blocks and cap off the graphite columns. The fluence, dpa, and temperatures are the same for the top insulator blocks.

Replaceable outer and inner reflector graphite blocks are placed on the inside and outside of the core ring. The inner reflector sees the highest temperatures and fluences. At the inside interface of the core ring, the fluence is $6.7 \mathrm{E} 20 \mathrm{n} / \mathrm{cm}^{2}$ per year $(\mathrm{E}>0.1 \mathrm{MeV})$ with a dpa of 0.56 per year. The peak fluence in the reflector block is $1.8 \mathrm{E} 20 \mathrm{n} / \mathrm{cm}^{2}$ per year with a dpa of 0.16 per year. Temperatures in the outer reflector blocks are $750^{\circ} \mathrm{C}$ for normal conditions and $1,100^{\circ} \mathrm{C}$ for off-normal conditions. Peak temperatures in the inner blocks are $850^{\circ} \mathrm{C}$ during normal operation conditions and $1,200^{\circ} \mathrm{C}$ during off-normal conditions.

The last graphite internal components are the fuel blocks. The active core is composed of three rings of fuel blocks, which see the highest temperatures and fluences of all the graphite components. The fluence

\section{GT-MHR Core Internals}

(Courtesy of General Atomics)

It it -5 is.
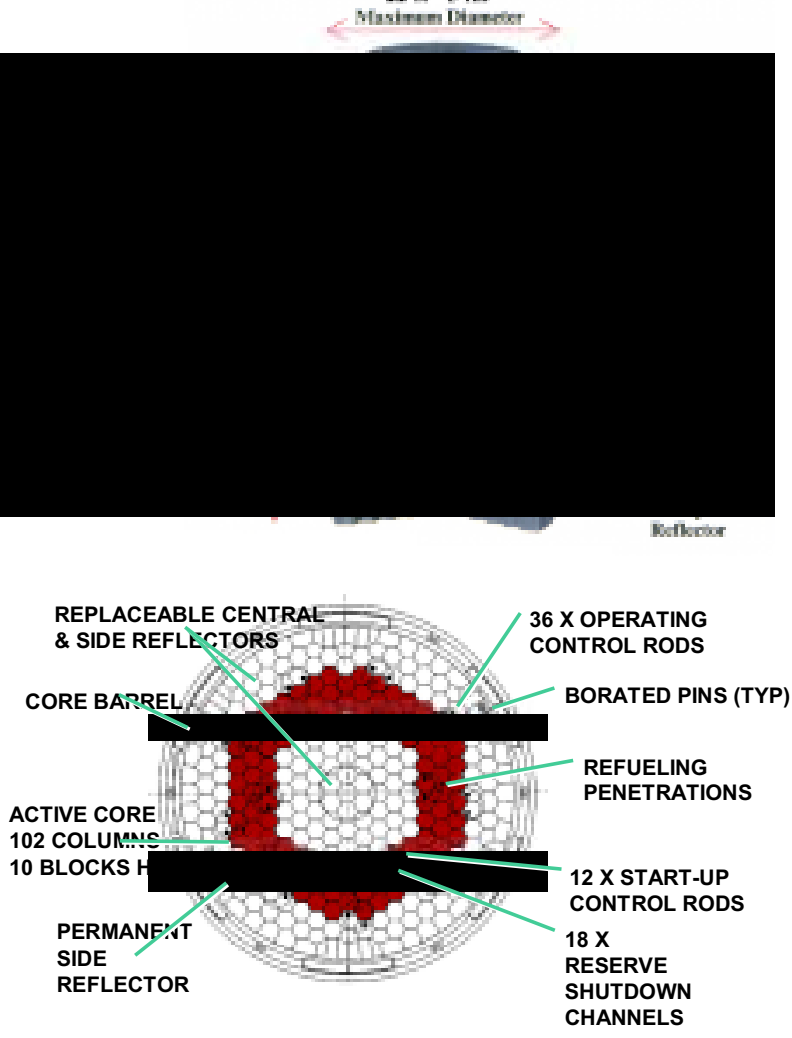

Figure 2-2. GT-MHR graphite core. 
is $9.9 \mathrm{E} 20 \mathrm{n} / \mathrm{cm}^{2}$ per year with a dpa of 0.82 per year. The normal operating peak temperatures for the fuel particles are kept below $1,250^{\circ} \mathrm{C}$. The block temperatures run about 100 to $200^{\circ} \mathrm{C}$ below the fuel particle temperatures. Off-Normal peak temperatures for the fuel particles are approximately $1,600^{\circ} \mathrm{C}$.

The graphite components of the PBMR are illustrated in Figure 2-3. The annular shaped reactor core, which is composed of a bed of fuel pebbles, is supported by the bottom reflector and is laterally restrained by the central reflector and side reflector. The central and side reflectors are constructed from stacks of large interlocking (keyed) graphite blocks. Figure 2-4 illustrates the central reflector and shows the interlocking and key-structure.

The currently designated graphite grades for the PBMR core internals are SGL NGB-10 and NGB-12. Both are extruded, pitch coke graphites manufactured at SGL's Chedde facility in France. The pitch coke used is the same as that currently used for the production of the UK AGR graphite fuel sleeves, and thus there is considerable production experience for this coke and graphite. Consideration is also being given to grade NGB-18, a vibrationally molded graphite.

The volume average thermal flux in the core is $7.90 \times 10^{13} \mathrm{n} / \mathrm{cm}^{2} . \mathrm{s}[\mathrm{E}>1.86 \mathrm{eV}]$. The volume average fast flux, which is more relevant because it is fast neutrons that displace carbon atoms and cause the dimensional and property changes, is $3.26 \times 10^{13} \mathrm{n} / \mathrm{cm}^{2} . \mathrm{s}[\mathrm{E}>0.1 \mathrm{MeV}]$. Typical lifetime fast fluences for the graphite core internals for a 35 effective full power year life are:

Fuel Pebbles

Upper reflector edge (maximum)

Outer reflector side (maximum)

Inner reflector side (maximum

Lower reflector edge (maximum)
$2.65 \times 10^{21} \mathrm{n} / \mathrm{cm}^{2}[\mathrm{E}>0.1 \mathrm{MeV}]$

$0.21 \times 10^{22} \mathrm{n} / \mathrm{cm}^{2}[\mathrm{E}>0.1 \mathrm{MeV}]$

$3.85 \times 10^{22} \mathrm{n} / \mathrm{cm}^{2}[\mathrm{E}>0.1 \mathrm{MeV}]$

$4.73 \times 10^{22} \mathrm{n} / \mathrm{cm}^{2}[\mathrm{E}>0.1 \mathrm{MeV}]$

$0.53 \times 10^{22} \mathrm{n} / \mathrm{cm}^{2}[\mathrm{E}>0.1 \mathrm{MeV}]$

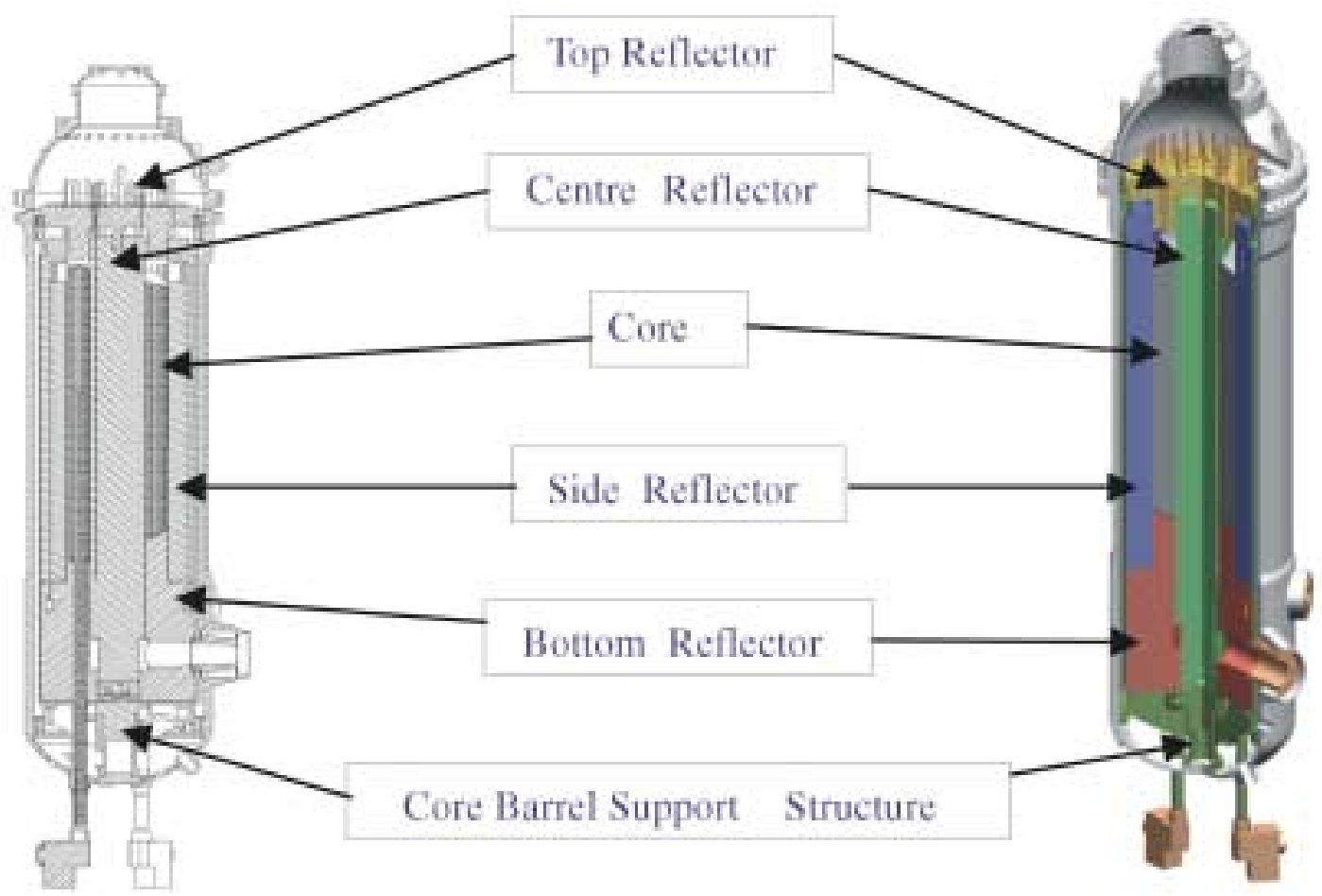

Figure 2-3. The graphite core internals of the Pebble Bed Modular Reactor. 

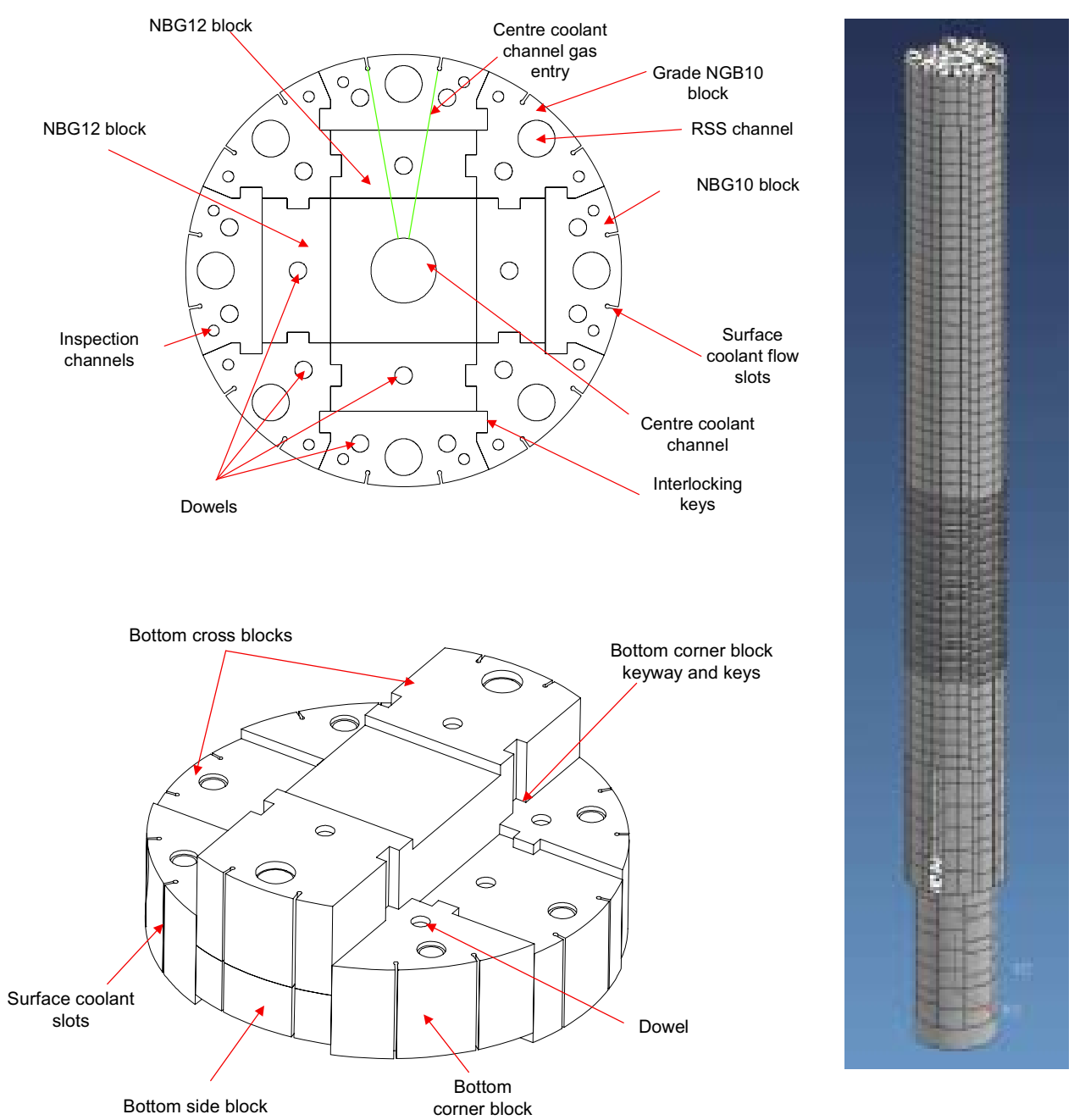

Figure 2-4. The central graphite column of the Pebble Bed Modular Reactor.

The neutron fluence to the central and side reflector is clearly very significant, potentially necessitating their replacement during the life of the reactor. Consequently, the graphite blocks of the central reflector and the inner side reflector (Figures 2-4 and 2-5) are designed to be removable. The average fuel temperature in the PBMR varies axially through the PBMR core. The fuel temperature is $\sim 500^{\circ} \mathrm{C}$ at the top of the core where the coolant gas enters and increases to $\sim 900^{\circ} \mathrm{C}$ at the reactor mid plane.

The peak mean fuel temperature is $\sim 1,000^{\circ} \mathrm{C}$ close to the bottom of the core. The maximum fuel temperature is $>1,000^{\circ} \mathrm{C}$ for much of the length of the core (above a core height of $4 \mathrm{~m}$ ). The PBMR peak fuel design temperature is $1160^{\circ} \mathrm{C}$. The peak graphite temperatures under normal operating conditions are also likely to be $\sim 1,000^{\circ} \mathrm{C}$. Consequently, those areas of the core (inner edge of the side reflector and the outer edge of the central reflector column) that experience high temperatures $\left(>600^{\circ} \mathrm{C}\right)$ and high neutron fluence $\left(>3.0 \times 10^{22} \mathrm{n} / \mathrm{cm}^{2}[\mathrm{E}>0.1 \mathrm{MeV}]\right)$ will experience significant distortion because of the irradiation induced shrinkage and growth. Temperature and fast neutron fluence gradients will also cause differential stresses in the core that will relax due to irradiation induced creep of the graphite. 


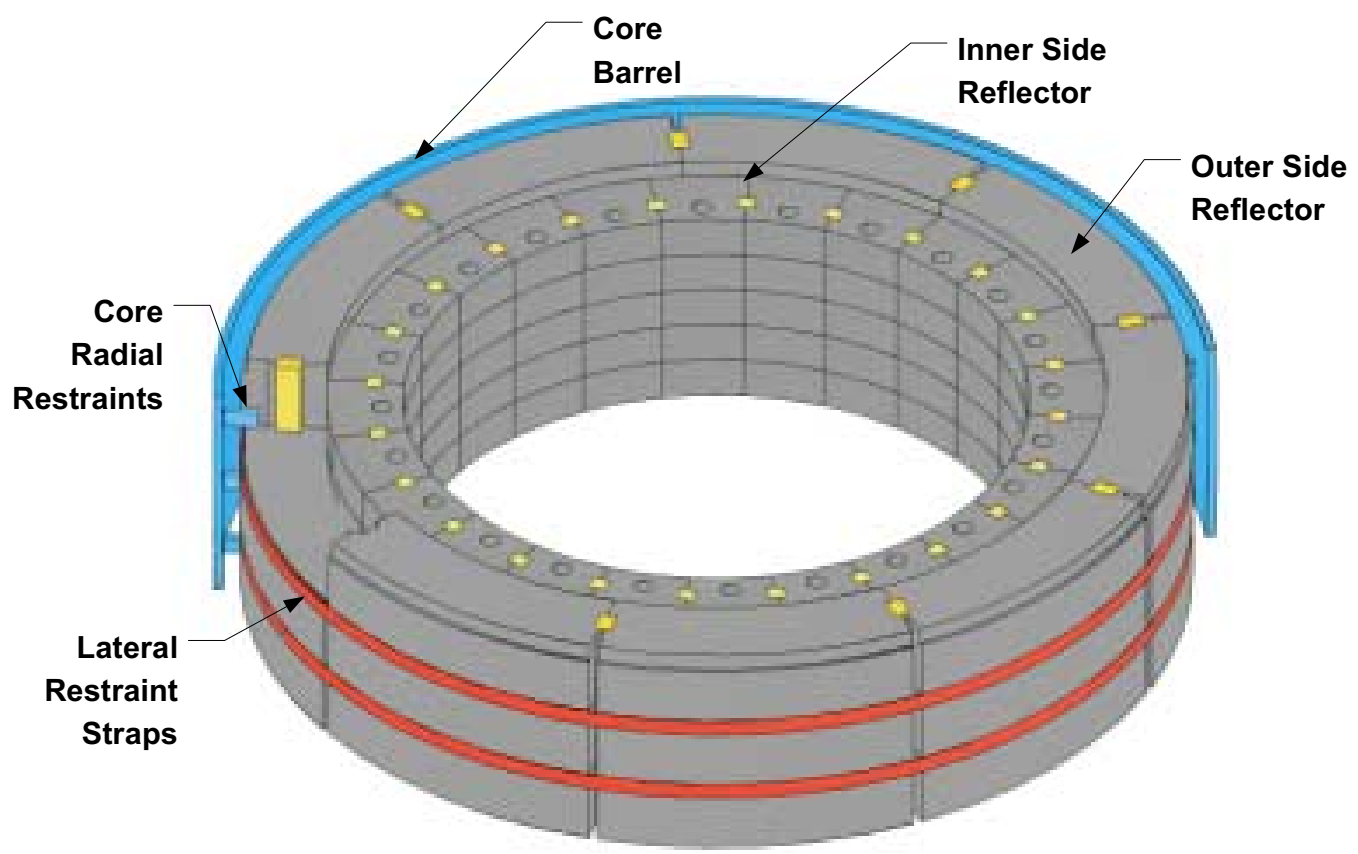

Figure 2-5. The inner and outer graphite side reflector of the Pebble Bed Modular Reactor. 


\section{GRAPHITE MANUFACTURE AND PROPERTIES}

Graphite is a composite material manufactured from a filler coke and pitch binder. Nuclear graphites are usually manufactured from isotropic cokes (petroleum or coal-tar derived) and are formed in a manner to make them nearisotropic or isotropic material. Figure 3-1 shows the major processing steps in the manufacturing of nuclear graphite. After baking (carbonization), the artifact is typically impregnated with a petroleum pitch and rebaked to densify the part. Impregnation and rebake may occur several times to attain the required density. Graphitization typically occurs at temperatures $>2,500^{\circ} \mathrm{C}$. Additional halogen purification may be required. Typical manufacturing times are 6-9 months.

The forming and densification processes will impart property variation within the billet. The properties will be somewhat different in the forming direction compared to the perpendicular to forming direction. Moreover, a density gradient will exist from billet edge to center. These variations must be quantified for the selected grades of graphite. In addition, variations in properties will arise from billet to billet within a batch and between production lots.

Finished graphite is machined to the complex geometries required for the reactor components (fuel elements, reflector blocks, core support post, etc.). Figure 3-2 shows a graphite fuel element from the HTTR undergoing machining.

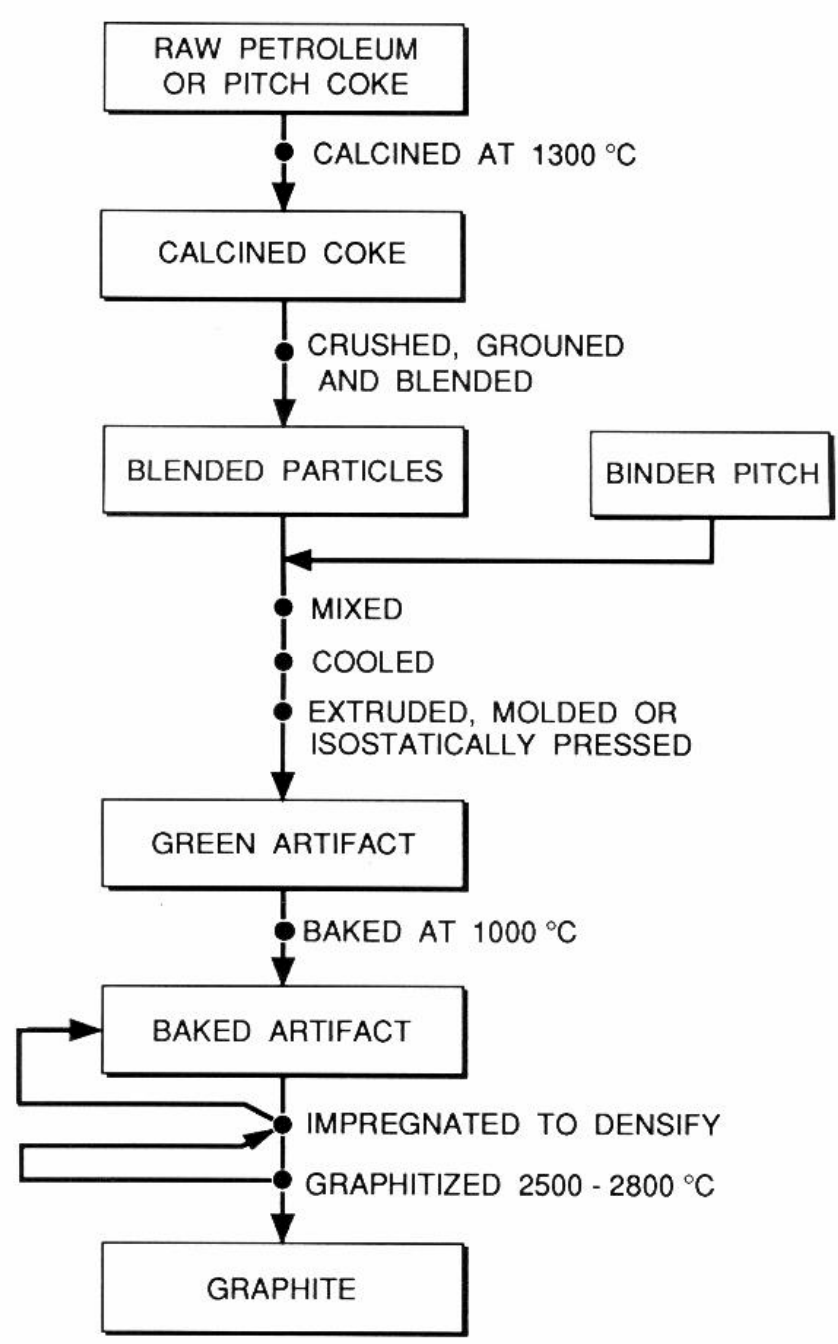

Figure 3.1. The process step in the manufacturing of nuclear graphite.

The grade of nuclear graphite $(\mathrm{H}-451)$ previously used in the USA is no longer available. New graphites have been developed and are currently being considered as candidates for the NGNP. Early in the program, we will review and document the existing data from all available sources on the properties of these graphites. Irradiation data from ongoing experiments in Petten Reactor (European program) will be of great value. A complete properties database on the new, available candidate grades of graphite must be developed to support the design of graphite core components. Data are required for the physical, mechanical (including radiation induced creep) and oxidation properties of graphites. Moreover, the data must be statistically sound and take account of in-billet, between billets, and lot-to-lot variations of properties. The data will be needed to support the ongoing development of the risk-informed American Society of Mechanical Engineers (ASME) graphite design codes. Previous Fort St. Vrain design used deterministic performance models for H-451, while the NGNP will use new graphite grades and risk-informed performance models. A radiation effects database must be developed for the currently 


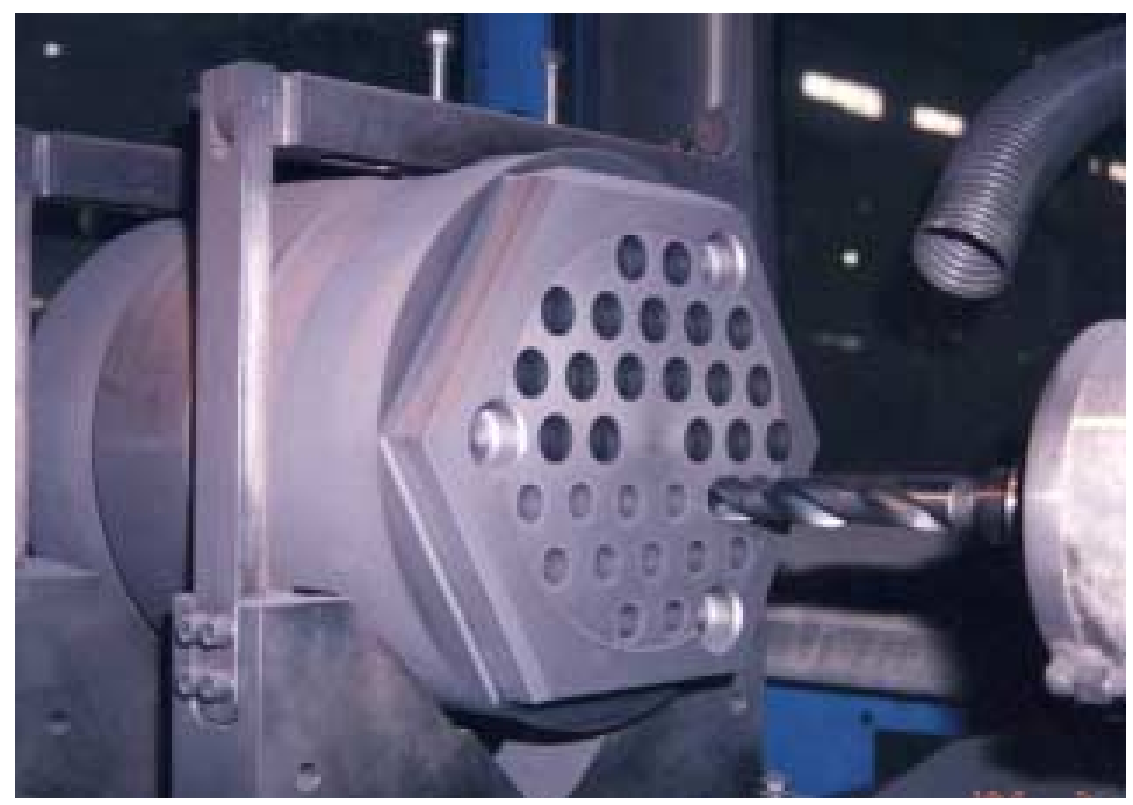

Figure 3-2. HTTR graphite fuel block undergoing machining.

available, graphite materials and this requires a substantial graphite irradiation program. There is the potential to leverage data from European Union activities in the area of irradiation experiments on PBMR graphites (Petten Reactor irradiation experiments are currently being initiated). Properties data must be obtained for the currently available graphites to support design activities for both the GT-MHR and the NGNP.

Candidate graphite materials are presented in Table 1. However, certain tests must be conducted to verify that the candidate's relevant material properties meet the claims of the manufacturer. The preliminary selection process will need limited irradiation response data for the different grades of graphite. These test results will be used to establish the general behavior of a particular grade of graphite and confirm that it behaves similarly to previously "qualified" (for other nuclear reactors), near-isotropic, nuclear grades of graphite.

Determining the irradiated behavior of these graphites is accomplished through irradiation of stressed and unstressed graphite specimens. The irradiated unstressed samples are used to measure the change in mechanical and thermal properties from unirradiated samples (e.g., dimensional inspection, mass, sonic velocity, sonic modulus, dynamic modulus, electrical resistivity, thermal conductivity and coefficient of thermal expansion). Measuring the difference in the dimensional change between stressed and unstressed samples yields a measure of the irradiation induced creep in the specimens. Figure 3-3 shows the AGC-1 Advanced Test Reactor (ATR) graphite capsule that will use the symmetry of the flux buckling in ATR to irradiate stressed and unstressed pairs of graphite specimens at the same neutron fluence levels.

The data acquired from AGC-1 and other planned irradiation capsules will be used in the numerical modeling of the physical behavior of the graphite. The modeling starts with taking into account the irradiated behavior of the physical properties of graphite. This takes the form of building mathematical expressions as a function of temperature and fluence for the property. The next step is to use the irradiated properties mathematical expressions in a numerical model of the graphite core using methods such as finite elements. The finite element model will be used to determine the effect of temperature and fluence on the structural response of the graphite core during its lifetime. This work will be discussed in more detail in a joint report between Idaho National Laboratory and Oak Ridge National Laboratory (ORNL) on the graphite core structural modeling available in July 2005. 
Table 1. Graphite selection matrix.

\begin{tabular}{|c|c|c|c|c|}
\hline Graphite & $\begin{array}{l}\text { Reactor } \\
\text { Vendor }\end{array}$ & Proposed Use & $\begin{array}{l}\text { Capsule } \\
\text { Location } \\
\end{array}$ & Remarks \\
\hline H-451 & GA & $\begin{array}{l}\text { Prismatic fuel element } \\
\text { and replaceable reflector. }\end{array}$ & Creep & $\begin{array}{l}\text { Historical Reference. } \\
\text { Only a few samples. }\end{array}$ \\
\hline IG-110 & $\begin{array}{l}\text { JAERI } \\
\text { China }\end{array}$ & $\begin{array}{l}\text { Prismatic fuel element, } \\
\text { replaceable reflector, and } \\
\text { core support pedestals. }\end{array}$ & Creep & $\begin{array}{l}\text { Historical Reference. } \\
\text { Only a few samples. } \\
\text { Currently being used in the HTTR and HTR- } \\
10 .\end{array}$ \\
\hline PCEA & AREVA & $\begin{array}{l}\text { Prismatic fuel and } \\
\text { replaceable block. } \\
\text { Pebble bed reflector and } \\
\text { insulation blocks. }\end{array}$ & Creep & $\begin{array}{l}\text { Areva wants to construct the entire graphite } \\
\text { core out of the same graphite. }\end{array}$ \\
\hline NBG-18 & PBMR & $\begin{array}{l}\text { Prismatic fuel element } \\
\text { and replaceable reflector. } \\
\text { Pebble bed reflector } \\
\text { structure and insulation } \\
\text { blocks. }\end{array}$ & Creep & Candidate for PBMR replaceable reflector. \\
\hline NBG-17 & AREVA & $\begin{array}{l}\text { Prismatic fuel element } \\
\text { and replaceable reflector. } \\
\text { Pebble bed; reflector } \\
\text { structure and insulation } \\
\text { blocks. }\end{array}$ & Creep & $\begin{array}{l}\text { Areva wants to construct the entire graphite } \\
\text { core out of the same graphite. } \\
\text { NBG-17 is finer grain than NBG-18. }\end{array}$ \\
\hline IG-430 & JAERI & $\begin{array}{l}\text { Prismatic fuel element, } \\
\text { replaceable reflector, and } \\
\text { core support pedestals. }\end{array}$ & Creep & $\begin{array}{l}\text { JAERI wants to use this graphite in the } \\
\text { GTHTR } 300 .\end{array}$ \\
\hline HLM & & $\begin{array}{l}\text { Prismatic large permanent } \\
\text { reflector. }\end{array}$ & Piggyback & $\begin{array}{l}\text { Fort St. Vrain permanent reflector. Similar to } \\
\text { PGX. }\end{array}$ \\
\hline PGX & $\begin{array}{l}\text { AREVA } \\
\text { JAERI }\end{array}$ & $\begin{array}{l}\text { Prismatic large permanent } \\
\text { reflector. }\end{array}$ & Piggyback & $\begin{array}{l}\text { AREVA may use this material; preference is } \\
\text { to use PCEA or NBG- } 17 \text { for permanent } \\
\text { reflector. HTTR permanent structure. }\end{array}$ \\
\hline NBG-25 & & Core support candidate. & Piggyback & Isostatic fine grain. \\
\hline 2020 & & $\begin{array}{l}\text { Prismatic core support } \\
\text { pedestals and blocks. }\end{array}$ & Piggyback & $\begin{array}{l}\text { Fine grain isotropic. } \\
\text { NPR candidate material. }\end{array}$ \\
\hline PCIB & & Core support candidate. & Piggyback & Fine grain isotropic. \\
\hline BAN & & & Piggyback & $\begin{array}{l}\text { Experimental graphite with potentially } \\
\text { superior irradiation life. }\end{array}$ \\
\hline NBG-10 & PBMR & $\begin{array}{l}\text { Prismatic Fuel element } \\
\text { and replaceable reflector. } \\
\text { Pebble bed; reflector } \\
\text { structure and insulation } \\
\text { blocks. }\end{array}$ & Piggyback & $\begin{array}{l}\text { PBMR's original choice for replaceable } \\
\text { reflector. } \\
\text { Price/performance will be the basis between } \\
\text { NBG-18 and NBG- } 10 \text {. }\end{array}$ \\
\hline HOPG & & $\begin{array}{l}\text { Needed to determine } \\
\text { change in crystalline } \\
\text { structure. }\end{array}$ & Piggyback & $\begin{array}{l}\text { Provides insight to single crystal changes } \\
\text { during neutron irradiation. }\end{array}$ \\
\hline $\begin{array}{l}\text { A3 } \\
\text { Matrix }\end{array}$ & & $\begin{array}{l}\text { Needed to determine fuel } \\
\text { compact irradiated } \\
\text { material behavior. }\end{array}$ & Piggyback & \\
\hline PPEA & & $\begin{array}{l}\text { Prismatic fuel and } \\
\text { replaceable block; } \\
\text { Pebble bed reflector and } \\
\text { insulation blocks }\end{array}$ & Piggyback & $\begin{array}{l}\text { Comparison of irradiation performance } \\
\text { between petroleum and pitch coke }\end{array}$ \\
\hline
\end{tabular}



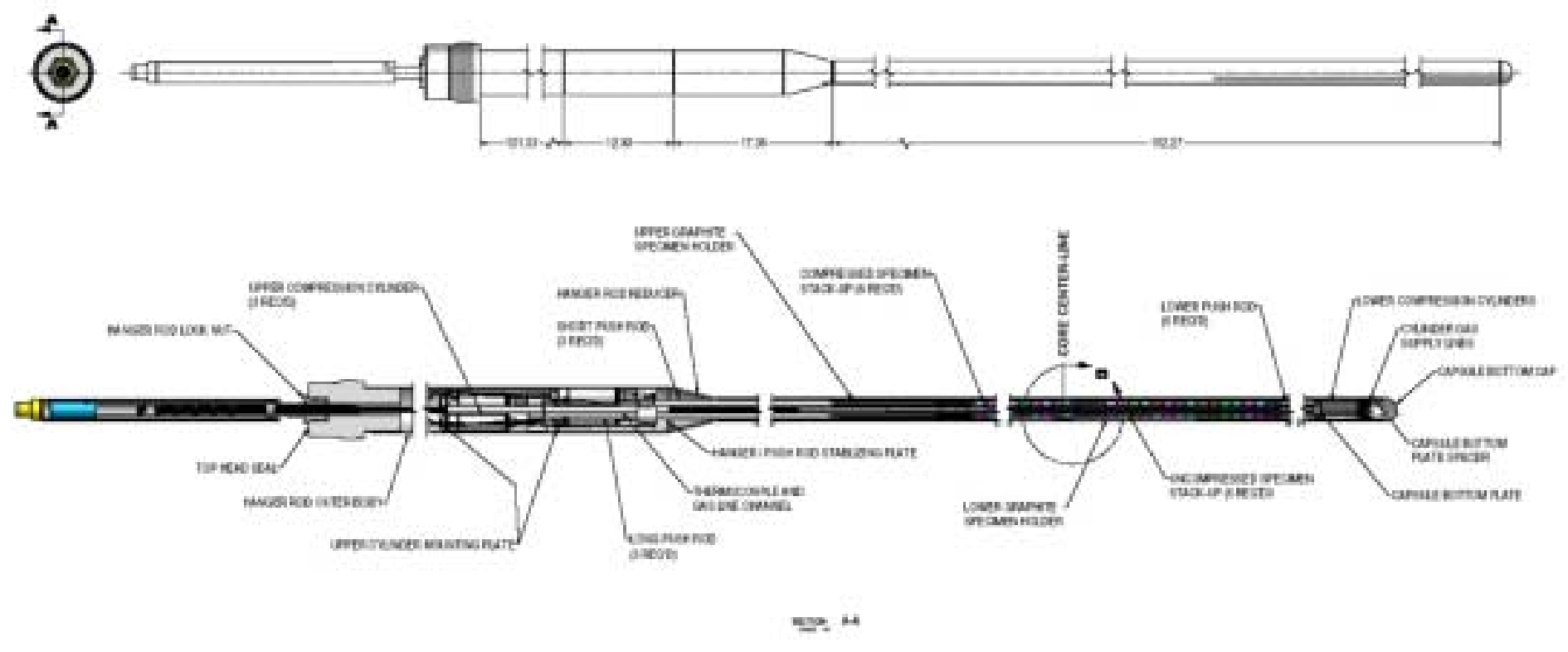

Figure 3-3. AGC-1 Advanced Test Reactor graphite irradiation capsule.

Nuclear graphite codes and standards development is required in support of the NGNP. ASTM standard test methods are required for determining key physical and mechanical properties, for example, the critical strain energy release rate $\left(\mathrm{K}_{\mathrm{Ic}}\right)$, the crystalinity of the graphite (by X-ray diffraction), coefficient of thermal expansion, and the air oxidation rate. ASME design codes must be developed for the graphite core supports structures and carbon-carbon composite structures to be used in the NGNP. Activities in support of the graphite design code have already been initiated by a task group under the auspices of ASME Section III. Carbon-carbon composites are required for NGNP components such as control rod structural elements, upper vessel insulation support structure, and insulation shroud covers. 


\section{AVAILABLE GRAPHITES}

The Generation IV International Forum (GIF) has a graphite materials activity described in the Graphite Collaboration Plan, developed by the GIF VHTR Materials and Components Project Management Board. The Graphite Collaboration Plan describes the activities being conducted internationally to develop a design database for the NGNP and other VHTR concepts. Moreover, the graphites being used by the GIF partners in their international programs are identified in the collaboration plan. An important aspect of this plan is the coordination of the acquisition of new nuclear grade graphites for Gen IV VHTR concepts. The consensus of GIF members' expert opinions recommended the selected graphites in this document based on the GIF VHTR Materials and Components Project Management Board Graphite Collaboration Plan. Moreover, the acquisition of the recommended grades has been coordinated through the Project Management Board such that the selected grades are from the same production batches. In many cases the production of significant-sized batches of new nuclear grades has been undertaken by the graphites suppliers, and thus no single nation has to bear the cost of a new production lot or batch of graphite.

As a result of the preliminary discussion on the graphite GIF plan in January 2005, GIF representatives met at the facilities for SGL Carbon and Graftech to review the work on developing new nuclear grade graphites. At the meetings with SGL, the new graphite grades NBG-18 and NBG-17 were discussed. SGL pledged minor quantities of these graphites for irradiation testing at no cost and agreements were reached for billet quantities of these graphites for future characterization programs. Similar arrangements were reached with Graftech for the new grade of graphite, PCEA. Graftech also pledged minor quantities of the experimental graphite BAN at no cost for use in irradiation testing. As of this time, no other graphite manufacturers have been contacted to determine if they would supply graphite for the irradiation capsule at no cost. Discussions with other graphite vendors will be conducted in the future. Graftech has yet to make a decision to commercially produce BAN. All other grades of graphite are available commercial graphite grades. 


\section{RECOMMENDED GRAPHITE STRATEGY}

It is recommended that one or more billets of the following graphite grades be purchased for inclusion in the US program. The actual graphite purchases and costs will be available in a letter report from ORNL describing the procurement of representative lots of graphite in early July 2005.

\subsection{Major Grades}

Billets of these grades should be purchased for inclusion in the USA irradiation program and for subsequent preirradiation characterization. Quantities needed for the irradiation and preirradiation characterization should be purchased this or next fiscal year. Billet quantities should be purchased when funding is available to perform a more extensive material characterization to determine variances form billet to billet and between lots. Both SGL and Graftech have pledged a sufficient quantity of the graphites PCEA, NBG-17 and -18 for irradiation testing at no cost.

\begin{tabular}{|l|l|l|}
\hline \multicolumn{1}{|c|}{ Grade } & \multicolumn{1}{|c|}{ Manufacturer } & \multicolumn{1}{c|}{ Comments } \\
\hline PCEA & Graftech International & Extruded, candidate for high dose regions of VHTR concepts \\
\hline NBG-17 & SGL & $\begin{array}{l}\text { Vibrationally molded, candidate for high dose regions of } \\
\text { VHTR concepts }\end{array}$ \\
\hline NBG-18 & SGL & $\begin{array}{l}\text { Vibrationally molded, candidate for high dose regions of } \\
\text { VHTR concepts }\end{array}$ \\
\hline IG-430 & Toyo Tanso & $\begin{array}{l}\text { Vibrationally molded, candidate for high dose regions of } \\
\text { VHTR concepts }\end{array}$ \\
\hline
\end{tabular}

\subsection{Minor Grades}

Billets of the following grades will be required for detailed characterization. Guidance from the reactor vendors will be used to determine which of these grades will be subjected to detailed characterization. Smaller quantities may have to be purchased for irradiation experiments, although in many cases these will be supplied free of cost by the manufacturers. Quantities needed for the irradiation and pre-irradiation characterization should be purchased this or next fiscal year. Billet quantities should be purchased when funding is available to perform a more extensive material characterization to determine variances from billet to billet and between lots.

\begin{tabular}{|l|l|l|}
\hline \multicolumn{1}{|c|}{ Grade } & \multicolumn{1}{|c|}{ Manufacturer } & \multicolumn{1}{c|}{ Comments } \\
\hline PGX & Graftech International & Molded, candidate for low dose regions of VHTR concepts \\
\hline PCIB & Graftech International & $\begin{array}{l}\text { Isostatically molded, candidate for low dose regions of VHTR } \\
\text { concepts }\end{array}$ \\
\hline NBG-10 & SGL & $\begin{array}{l}\text { Extruded, candidate for low and high dose regions of VHTR } \\
\text { concepts }\end{array}$ \\
\hline NBG-25 & SGL & Extruded, candidate for low dose regions of VHTR concepts \\
\hline HLM & SGL & Extruded, candidate for low dose regions of VHTR concepts \\
\hline 2020 & Carbone of America & $\begin{array}{l}\text { Isostatically molded, candidate for low dose regions of VHTR } \\
\text { concepts }\end{array}$ \\
\hline PPEA & Graftech International & Extruded, candidate for low dose regions of VHTR concepts \\
\hline
\end{tabular}




\subsection{Experimental and Research Grades}

The following grades will be included in our irradiation experiments only, no characterization is planned, and thus purchases costs will be minimal.

\begin{tabular}{|l|l|l|}
\hline \multicolumn{1}{|c|}{ Grade } & \multicolumn{1}{|c|}{ Manufacturer } & \multicolumn{1}{c|}{ Comments } \\
\hline BAN & Graftech International & Extruded, candidate for high dose regions of VHTR concepts \\
\hline HOPG & Advanced Ceramics & $\begin{array}{l}\text { Vapor deposited and compression annealed. A model material } \\
\text { for the graphite single crystal }\end{array}$ \\
\hline A3-matrix & $\begin{array}{l}\text { Oak Ridge National } \\
\text { Laboratory }\end{array}$ & $\begin{array}{l}\text { Hot pressed graphite/carbon used for the matrix of AGFR fuel } \\
\text { compacts }\end{array}$ \\
\hline
\end{tabular}




\section{REFERENCES}

1. T. D. Burchell, "Fission Reactor Applications of Carbon," In: Carbon Materials for Advanced Technologies, T. D. Burchell (Editor). Chapter 13, pp. 429-484, Pub. Elsevier Science Ltd, 1999. 